\title{
Bioethanol production by Saccharomyces cerevisiae, Pichia stipitis and Zymomonas mobilis from delignified coconut fibre mature and lignin extraction according to biorefinery concept
}

\author{
Fabiano Avelino Gonçalves ${ }^{\mathrm{a}, \mathrm{b}}$, Héctor A. Ruiz ${ }^{\mathrm{b}, \mathrm{c}}$, Everaldo Silvino dos Santos ${ }^{\mathrm{a}}$, \\ José A. Teixeira ${ }^{\mathrm{b}}$, Gorete Ribeiro de Macedo ${ }^{\mathrm{a},{ }^{*}}$ \\ ${ }^{a}$ Laboratory of Biochemical Engineering, Chemical Engineering Department, Federal University of Rio Grande do Norte, 59078-970 Natal, Brazil \\ b Centre of Biological Engineering, University of Minho, Campus de Gualtar, 4710-057 Braga, Portugal \\ c Biorefinery Group, Food Research Department, School of Chemistry, Autonomous University of Coahuila, 25280 Saltillo, Coahuila, Mexico
}

\section{A R T I C L E I N F O}

\section{Article history:}

Received 11 September 2015

Received in revised form

1 February 2016

Accepted 9 March 2016

\section{Keywords:}

Hydrothermal pretreatment

Bioethanol

Lignin

Phenolics

Biorefinery

Fermentation

\begin{abstract}
A B S T R A C T
In search to increase the offer of liquid, clean, renewable and sustainable energy in the world energy matrix, the use of lignocellulosic materials (LCMs) for bioethanol production arises as a valuable alternative. The objective of this work was to analyze and compare the performance of Saccharomyces cerevisiae, Pichia stipitis and Zymomonas mobilis in the production of bioethanol from coconut fibre mature (CFM) using different strategies: simultaneous saccharification and fermentation (SSF) and semisimultaneous saccharification and fermentation (SSSF). The CFM was pretreated by hydrothermal pretreatment catalyzed with sodium hydroxide (HPCSH). The pretreated CFM was characterized by X-ray diffractometry and SEM, and the lignin recovered in the liquid phase by FTIR and TGA. After the HPCSH pretreatment $\left(2.5 \%(\mathrm{v} / \mathrm{v})\right.$ sodium hydroxide at $180^{\circ} \mathrm{C}$ for $\left.30 \mathrm{~min}\right)$, the cellulose content was $56.44 \%$, while the hemicellulose and lignin were reduced $69.04 \%$ and $89.13 \%$, respectively. Following pretreatment, the obtained cellulosic fraction was submitted to SSF and SSSF. Pichia stipitis allowed for the highest ethanol yield - 90.18\% - in SSSF, 91.17\% and 91.03\% were obtained with Saccharomyces cerevisiae and Zymomonas mobilis, respectively. It may be concluded that the selection of the most efficient microorganism for the obtention of high bioethanol production yields from cellulose pretreated by HPCSH depends on the operational strategy used and this pretreatment is an interesting alternative for add value of coconut fibre mature compounds (lignin, phenolics) being in accordance with the biorefinery concept.
\end{abstract}

๑) 2016 Elsevier Ltd. All rights reserved.

\section{Introduction}

The emerging need to obtain clean, low cost and renewable energy in support of a sustainable energy matrix, demands for the development of biotechnology processes, as is the case of the production of biofuels, that will contribute to the energetic selfsufficiency worldwide. USA and Brazil have achieved a situation close to ideal as from the bioethanol production "food source" with innumerable economic gains. Being a step toward energetic sustainability, the matrix becomes more "green", but does not fully

\footnotetext{
* Corresponding author.

E-mail addresses: fabiano_avelinogoncalves@yahoo.com.br (F.A. Gonçalves), hector_ruiz_leza@uadec.edu.mx (H.A. Ruiz), everaldo@eq.ufrn.br (E. Silvino dos Santos), jateixeira@deb.uminho.pt (J.A. Teixeira), gomacedo@eq.ufrn.br (G.R. de Macedo).
}

satisfy the socio-environmental issues and global geographic distribution. In this regard, an alternative solution is the bioethanol production from LCMs and other non-food source of carbohydrates, available according to the location, making possible a global production of this biofuel. However, some barriers are present in the production of cellulosic ethanol at commercial scale, especially the stages of pretreatment, enzymatic hydrolysis processing, fermentation (hexose and pentose) and the integral use of the raw material. There is also a need to select raw materials, according to the regions, that can be employed as substrate to produce bioethanol.

Brazil makes use of high amounts of sugarcane for the production of bioethanol and generates as waste straw and bagasse. However, in the current conjuncture of the Brazilian sugar and bioethanol production model, these residues are generally intended for electricity production [1], making uncertain its use for ethanol. As an alternative to mitigate this possible absence of 
residues from sugarcane, Brazil possesses raw materials from several other crops as it the case of the coconut residue (known as CFM). The cultivation of coconut is distributed in more than 200 countries and global production in 2009 was about 55 million tons [2]. Brazil is the fourth largest producer, with a production of about 3 million tonnes (5\%), the Northeast Region accounting for $82.28 \%$ of the total cultivated area [3]. Gonçalves et al. [4] reported that the estimated content of bagasse (fibre) in the coconut in $50 \%$.

For the production of second generation bioethanol within the biorefinery concept, a pretreatment stage for the fractionation of the material is necessary, with the finality of increasing the susceptibility of the material to enzymatic attack. Yang and Wyman [5] reported that the pretreatment stage is the most expensive step in bioethanol production. Pretreatment of LCMs are based on physical, chemical, biological, physicochemical and combined processes and are a key factor in the economic efficiency and one of the main challenges in large-scale production of ethanol [6].

According to Park et al. [7], the thermochemical pretreatment process is now regarded as the most effective one, being $\mathrm{pH}$ and temperature the main parameters to be considered. The alkaline pretreatment is used with the intention to remove mainly the lignin. Sodium hydroxide, calcium hydroxide and ammonia are highlighted in this pretreatment due to the low cost and the need of smaller enzymatic loads to convert cellulose into glucose [7]. The use of sodium hydroxide as catalyst pretreatment by steam explosion was carried out by Park et al. [7] and resulted in an elevated delignification and effective enzymatic hydrolysis on Eucalyptus grandis. Because a minimal reduction of the lignin on the solid phase in the LCM pretreated by steam explosion occurs [7], similar facts take place with the LCM pretreated by autohydrolysis [8]. Therefore, the use of sodium hydroxide in hydrothermal pretreatment consists an alternative to reduce the lignin content of the LCM, as used by Rawat et al. [9] in poplar (Populus deltoides) and Kim and Han [10] on rice straw.

During this pretreatment, the hemicellulose is degraded to low molecular weight oligomers, monomers and organic acids that form a black liquor [11]. Additionally, the black liquor contains a high lignin concentration and phenolic compounds, the recovery of lignin from the liquor being done by the acid precipitation method and converted into synthesis gas or as used as raw material for several aromatic substances of low molecular weight [11,12]. The phenolic compounds are natural sources of antioxidants and may be applied as food additives and cosmetic applications $[8,13]$.

Several strategies for the production of cellulosic ethanol may be applied at the fermentation stage, for example, separate hydrolysis and fermentation (SHF) and simultaneous saccharification and fermentation (SSF). Attributes of SSF are less inhibition of enzyme and longer time of EH compared to SHF; SHF possesses a greater rate of hydrolysis [14]. As an alternative to merge the advantages provided by SHF and SSF, arises the use of semisimultaneous saccharification and fermentation (SSSF) which includes a presaccharification stage before SSF [15]. SSSF is expected to have higher productivity and yield than SSF and SHF on their own, if the presaccharification time is appropriate [14,16].

Therefore, this work aims to evaluate a strategy for the application of CFM as a raw material for bioethanol production by carrying a HPCSH step followed by two alternative fermentation strategies - SSF and SSSF - using three fermenting microorganisms - Saccharomyces cerevisiae, Pichia stipitis and Zymomonas mobilis and characterization of lignin obtained in the liquid phase.

\section{Materials and methods}

\subsection{Raw material and chemical characterization}

CFM was obtained from the agroindustries locations in the Northeast of Brazil. Chemical characterization was performed by quantitative acid hydrolysis with $5 \mathrm{~mL}$ of $72 \%$ (w/w) sulfuric acid for $1 \mathrm{~h}$ and quantitative post-hydrolysis with $4 \%$ sulfuric acid (adding water until $148.67 \mathrm{~g}$ ) at $121{ }^{\circ} \mathrm{C}$ during $1 \mathrm{~h}$. Before HPLC analysis, the solid residue from post-hydrolysis process was recovered by filtration and considered as Klason lignin. Monosaccharides sugars and acetic acid contained in the hydrolysates were determined by HPLC in order to estimate the contents of samples of cellulose and hemicellulose [15]. Composition of LCMs was determined according to the protocols of the a National Renewable Energy Laboratory [17]. Residual ash content was estimated from $2 \mathrm{~g}$ sample maintained at $550{ }^{\circ} \mathrm{C}$ for $5 \mathrm{~h}$ and weighed to measure the residual ash content [18]. The moisture was estimated from a $2 \mathrm{~g}$ sample maintained at $105^{\circ} \mathrm{C}$ for $24 \mathrm{~h}$ and weighed to calculate the residual content [17].

\subsection{Pretreatment process}

\subsubsection{Preparation of raw material before the pretreatment}

The CFM was washed for the removal of non-lignocellulosic residues. After five washes with water at $70^{\circ} \mathrm{C}$, the material was dried in an oven with air circulation at $40{ }^{\circ} \mathrm{C}$ for $24 \mathrm{~h}$. After this procedure, the CFM was milled into a particle size of 48 mesh $(0.3 \mathrm{~mm})$, with the purpose of standardizing the granulometry of the CFM [15].

\subsubsection{Hydrothermal pretreatment catalyzed with sodium hydroxide (HPCSH)}

The CFM, sodium hydroxide and water were mixed in order to obtain a 10:1 liquid/solid ratio, the conditions of HPCSH are shown in Table 1. These experiments were carried out in $50 \mathrm{~mL}$ total volume stainless steel cylinders reactors. The reactor was closed and mounted vertically and then submerged in a Julabo oil bath open heating circulator (Julabo, Germany) with PID temperature control, previously heated to the desired reaction temperature (Table 1). At

Table 1

Operational conditions of pretreatment.

\begin{tabular}{|c|c|c|c|c|c|c|}
\hline \multirow[t]{4}{*}{ Assay } & \multicolumn{6}{|c|}{ Operational conditions } \\
\hline & \multicolumn{3}{|c|}{ Normalized variables } & \multicolumn{3}{|l|}{ Real value } \\
\hline & \multirow{2}{*}{$\frac{\mathrm{T}\left({ }^{\circ} \mathrm{C}\right)}{\mathrm{X}_{1}}$} & \multirow{2}{*}{$\frac{t(\min )}{x_{2}}$} & \multirow{2}{*}{$\frac{\mathrm{NaOH}(\%)}{\mathrm{X}_{3}}$} & \multirow{2}{*}{$\frac{\left({ }^{\circ} \mathrm{C}\right)}{\text { Temperature }}$} & \multirow{2}{*}{$\frac{(\min )}{\text { Time }}$} & \multirow{2}{*}{$\frac{(\%)}{\mathrm{NaOH}}$} \\
\hline & & & & & & \\
\hline \multicolumn{7}{|l|}{ Lineal } \\
\hline 1 & -1 & -1 & -1 & 160 & 10 & 1.0 \\
\hline 2 & -1 & -1 & 1 & 160 & 10 & 4.0 \\
\hline 3 & -1 & 1 & 1 & 160 & 50 & 4.0 \\
\hline 4 & -1 & 1 & -1 & 160 & 50 & 1.0 \\
\hline 5 & 1 & -1 & -1 & 200 & 10 & 1.0 \\
\hline 6 & 1 & -1 & 1 & 200 & 10 & 4.0 \\
\hline 7 & 1 & 1 & 1 & 200 & 50 & 4.0 \\
\hline 8 & 1 & 1 & -1 & 200 & 50 & 1.0 \\
\hline \multicolumn{7}{|c|}{ Central point } \\
\hline 9 & 0 & 0 & 0 & 180 & 30 & 2.5 \\
\hline 10 & 0 & 0 & 0 & 180 & 30 & 2.5 \\
\hline \multicolumn{7}{|c|}{ Quadratics } \\
\hline 11 & -1 & 0 & 0 & 160 & 30 & 2.5 \\
\hline 12 & 1 & 0 & 0 & 200 & 30 & 2.5 \\
\hline 13 & 0 & -1 & 0 & 180 & 10 & 2.5 \\
\hline 14 & 0 & 1 & 0 & 180 & 50 & 2.5 \\
\hline 15 & 0 & 0 & -1 & 180 & 30 & 1.0 \\
\hline 16 & 0 & 0 & 1 & 180 & 30 & 4.0 \\
\hline
\end{tabular}


the end of the desired reaction time (Table 1 ), the reactor was removed from the oil bath and cooled down by soaking in an icewater bath for $5 \mathrm{~min}$. The solid and liquid (liquor) were separated via vacuum filtration, both being characterized as mentioned in the Sections 2.3 and 2.4. The experiments were performed in duplicate.

\subsubsection{Experimental design and statistical analysis}

In order to relate the dependent variable cellulose (cellulose, \%) and independent variables temperature $\left(\mathrm{X}_{1},{ }^{\circ} \mathrm{C}\right)$, time $\left(\mathrm{X}_{2}, \mathrm{~min}\right)$ and sodium hydroxide concentration $\left(\mathrm{X}_{3}, \%\right)$ on pretreated CFM, with the minimum possible number of experiments, a $2^{3}$ central composite experimental design (CCD) for three factors that enabled the construction of a second-order polynomial in the independent variables and the identification of statistical significance in the variables was used.

The mathematical model (Equation (1)) corresponding to the experimental design is:

$$
\begin{aligned}
Y_{i}= & \beta_{0}+\beta_{1} X_{1}+\beta_{2} X_{2}+\beta_{3} X_{3}+\beta_{11} X_{1}^{2}+\beta_{22} X_{2}^{2}+\beta_{33} X_{3}^{2} \\
& +\beta_{12} X_{1} X_{2}+\beta_{13} X_{1} X_{3}+\beta_{23} X_{2} X_{3}
\end{aligned}
$$

where:

$Y_{i}=$ response function (cellulose \%);

$X_{1}, X_{2}, X_{3}=$ values of the independent variables;

$\beta_{0}=$ coefficient relating the interception of the plane with the axis of response;

$\beta_{1}, \beta_{2}, \beta_{3}=$ linear coefficients estimated by the method of least squares;

$\beta_{11}, \beta_{22}, \beta_{33}=$ coefficient of the quadratic variables;

$\beta_{12}, \beta_{13}, \beta_{23}=$ coefficient of the interaction between the independent variables.

The quality of the fit of the polynomial model equation was evaluated by the coefficient of determination $R^{2}$ and the statistical significance was evaluated by the Fisher's F-test for analysis of variance (ANOVA) with a 95\% confidence level. The effect of each independent variable and also their interaction effects were determined. ANOVA results generated the Pareto charts of interactions and effects. Experimental design package Statistica was the software used for data analysis.

\subsection{Characterization of pretreated solids}

\subsubsection{Chemical composition after the pretreatment}

The chemical composition was performed as described above (see Section 2.1.).

2.3.1.1. X-ray diffraction analysis. Cellulose crystallinity of pretreated and untreated CFM were analyzed using X-ray diffractometry (Bruker D8 Discover, USA). Determinations were made operating with radiation from copper $\mathrm{K} \alpha$, voltage of $40 \mathrm{kV}$, electrical current of $40 \mathrm{~mA}$ and speed of $2^{\circ}$ per minute using continuous scanning angle $2 \theta$ from 4 to 70 . The crystallinity index (CI) was defined using the Equation (2) [19].

$\mathrm{CI}=\frac{\mathrm{I}_{002}-\mathrm{I}_{\mathrm{am}}}{\mathrm{I}_{002}} \cdot 100$

where,

$\mathrm{I}_{002}=$ maximum intensity $\left(2 \theta, 22.6^{\circ}\right)$ of the (002) lattice diffraction;

$\mathrm{I}_{\mathrm{am}}=$ intensity of the amorphous diffraction $\left(2 \theta, 18.7^{\circ}\right)$.
2.3.1.2. Scanning electron microscopy. The scanning electron microscopy (SEM) surface of pretreated and untreated CFM were visualized by a scanning electron microscope (Nova NanoSEM 200, Netherlands) and photographed. Samples were initially coated with a gold layer by a cathodic sputtering process on voltage of $15 \mathrm{kV}$ and afterwards visualized by SEM.

\subsection{Characterization of liquid phase (liquor)}

\subsubsection{Liquor composition}

The liquors were analyzed by HPLC (see Section 2.9.). The following terms correspond to the stoichiometric factor for the conversion of xylan into xylose or arabinan into arabinose (132/ $150)$, xylan into furfural (132/96), acetyl groups into acid acetic (43/ $60)$, cellulose into glucose $(162 / 180)$ and cellulose into HMF (162/ 126) [20].

\subsubsection{Total phenolic compounds}

Total phenolic contents of liquor samples were determined by spectrophotometry using Folin-Ciocalteu reagent [21]. $100 \mu \mathrm{L}$ of liquor, $2 \mathrm{~mL}$ of sodium carbonate solution, $500 \mu \mathrm{L}$ of Folin-Ciocalteu reagent and $7.5 \mathrm{~mL}$ of distilled water were added in a tube. The tubes were placed in a water bath at $50^{\circ} \mathrm{C}$ for $5 \mathrm{~min}$, cooled down at room temperature and agitated in the vortex. The absorbance of the samples was measured at $700 \mathrm{~nm}$ using gallic acid as a standard. A seven point standard curve $(0-2000 \mathrm{mg} / \mathrm{L})$ made possible to quantify the contents of total phenolics (in triplicate).

\subsubsection{Acid precipitation of lignin in the liquor}

Acid precipitation was used to recover the lignin present in liquors. This fraction could be precipitated together with hemicelluloses causing impurities. For that purpose the liquids were acidified to $\mathrm{pH}=2$ with sulfuric acid at $72 \%(\mathrm{w} / \mathrm{w})$ and the acidic insoluble fraction was stored for $48 \mathrm{~h}$ to decant, washed and dried at $50{ }^{\circ} \mathrm{C}$ until constant weight (modified from Egüés et al. [11]).

Theoretical solubilized lignin (TSL) was calculated by Equation (3):

$$
\begin{aligned}
T S L(g)= & ((S L \times 0.1) \times(I L \times 0.1))+((Y L \times 0.1) \times(I L-P L) \\
& \times 0.1)
\end{aligned}
$$

where,

\section{SL: \% solubilized LCM;}

IL: \% lignin of LCM untreated;

YL: \% LCM unsolubilized;

PL: \% lignin of LCM pretreated.

\subsection{Characterization of lignin contained in the liquor after CFM pretreatment}

\subsubsection{Fourier-transform infrared spectra of lignin}

Fourier-transform infrared (FTIR) spectra of lignin of pretreated CFM was obtained on an FTIR spectrophotometer (FTLA 2000 series, ABB Bomem Inc., Quebec, Canada). The conditions of analysis were as resolution $4 \mathrm{~cm}^{-1}$, using 20 scans and frequency range of $500-4000 \mathrm{~cm}^{-1}$.

\subsubsection{Thermogravimetric analysis of lignin}

Thermogravimetric analysis (TGA) was performed using a Shimadzu TGA-50 equipment (Shimadzu Corporation, Japan), with thermal software TASYS. Samples were weighed (between 10 and $15 \mathrm{mg}$ ) in aluminium sample pans. The experiments were conducted under $\mathrm{N}_{2}$ atmosphere, at a heating rate of $10^{\circ} \mathrm{C} / \mathrm{min}$ over a 
temperature range between 20 and $600{ }^{\circ} \mathrm{C}$.

\subsection{Enzyme}

Enzyme solutions, cellulases, $\beta$-glucosidase and hemicellulases (Cellic CTec2) and endoxylanase (Cellic HTec2) were kindly supplied by Novozymes A/S (Bagsvaerd, Denmark). The total cellulase activity from Cellic CTec2 was analyzed in accordance with the standard methodology established by Mandels et al. [22]. In a tube were added $0.3 \mathrm{~mL}$ of the commercial enzyme diluted and $1.2 \mathrm{~mL}$ of sodium citrate buffer $0.5 \mu \mathrm{M}$ at $\mathrm{pH}=4.8$ and $50 \mathrm{mg}$ Whatman filter paper No. 1 as substrate. The medium was incubated in a water bath at $50{ }^{\circ} \mathrm{C}$ for $1 \mathrm{~h}$, the glucose liberated was measured using the DNS method. For Cellic CTec2 enzyme, the $\beta$-glucosidase activity was also determined. The $\beta$-glucosidase activity was measured by incubating the enzyme solution with $15 \mu \mathrm{M}$ of cellobiose and $50 \mathrm{mM}$ sodium citrate buffer $(\mathrm{pH}=4.8)$ at $50{ }^{\circ} \mathrm{C}$ for $30 \mathrm{~min}$. The reaction was stopped by immersing in water. Then, the concentration of glucose was determined using the GOD-POD method at room temperature for $10 \mathrm{~min}$ and the amount of glucose measured spectrophotometrically at $500 \mathrm{~nm}$. One unit of enzyme activity $(\mathrm{CBU} / \mathrm{mL})$ was defined as the release of $1 \mu \mathrm{mol}$ of glucose per minute. The xylanase activity was determined for HTec2. Reaction mixtures contained $0.1 \mathrm{~mL}$ enzyme and $0.5 \%(\mathrm{w} / \mathrm{v})$ of oat spelts xylan solution in acetate buffer, $\mathrm{pH}$ 5.0. The mixture was incubated at $50{ }^{\circ} \mathrm{C}$ for $10 \mathrm{~min}$. After a predetermined period, the released reducing sugars were quantified by DNS method measured spectrophotometrically at $535 \mathrm{~nm}$ [23]. One unit of xylanase activity $(\mathrm{IU} / \mathrm{mL})$ was defined as the amount of enzyme that released $1 \mu \mathrm{mol}$ product per min under the assay conditions. The initial enzyme activities were $126 \mathrm{FPU} / \mathrm{mL}$ of cellulase, $269 \mathrm{CBU} / \mathrm{mL}$ of $\beta$-glucosidase for Cellic CTec2 kit and $1654 \mathrm{IU} / \mathrm{mL}$ of endoxylanase for Cellic HTec2 kit.

\subsection{Enzymatic hydrolysis}

The enzymatic hydrolysis (EH) of delignified pretreated solid of CFM was performed to measure the susceptibility of the pretreated material. EH was performed with $4 \%(\mathrm{w} / \mathrm{v})$ of delignified pretreated solid of CFM, in an Erlenmeyer flask with a volume of $48 \mathrm{~mL}$ at $50^{\circ} \mathrm{C}$, using the enzymatic kit of Cellic CTec 2 and Cellic HTec 2 with an enzyme loading of $30 \mathrm{FPU}, 75 \mathrm{CBU}$ and $130 \mathrm{IU}$ per gram of pretreated solid, respectively, in $50 \mathrm{mM}$ sodium citrate buffer with $0.02 \%(\mathrm{w} / \mathrm{v})$ sodium azide to prevent microbial growth. The agitation was maintained at $150 \mathrm{rpm}$ for $96 \mathrm{~h}$. The samples were taken at $6 \mathrm{~h}$ intervals for the first $12 \mathrm{~h}$ and $12 \mathrm{~h}$ intervals until a total time of $96 \mathrm{~h}[24,25]$. All determinations were performed in duplicate. Concentrations of sugars were determined by HPLC (see Section 2.9). The yield of enzymatic hydrolysis was calculated using Equation (4) [24].

Hydrolysis yield $(\%)=\frac{[\text { glucose }]+1.053[\text { cellobiose }]}{1.111 \mathrm{f} \cdot[\text { biomass }]} \cdot 100$

where:

glucose $=$ concentration of glucose $(\mathrm{g} / \mathrm{L})$;

cellobiose $=$ concentration of cellobiose $(\mathrm{g} / \mathrm{L})$;

biomass $=$ concentration of dry biomass initial of enzymatic hydrolysis $(\mathrm{g} / \mathrm{L})$;

$\mathrm{f}=$ constitutes of the cellulose fraction of dry biomass $(\mathrm{g} / \mathrm{g})$;

$1.111=$ consists in the conversion factor of cellulose to glucose equivalent;

$1.053=$ consists in the conversion factor of cellobiose to glucose equivalent.

\subsection{Fermentative process}

\subsubsection{Microorganisms}

P. stipitis Y7124, S. cerevisiae PE2 and Z. mobilis B14023 strains were used in the production of bioethanol and obtained from the microbiological collection of the Centre of Biological Engineering at the University of Minho. Microorganisms were maintained in glycerol in Eppendorf tubes at $-80^{\circ} \mathrm{C}$ and subsequently lyophilized for use as a working stock.

\subsubsection{Inoculum preparation}

$S$. cerevisiae and $P$. stipitis were maintained in Petri dishes containing PDA (potato dextrose agar) culture medium and Z. mobilis was maintained in Petri dishes containing PCA (plate count agar) culture medium at $30^{\circ} \mathrm{C}$ for $24 \mathrm{~h}$. The strains for inoculation were grown in $250 \mathrm{~mL}$ Erlenmeyer flasks with $100 \mathrm{~mL}$ of sterile culture medium containing $50 \mathrm{~g} / \mathrm{L}$ glucose, $1 \mathrm{~g} / \mathrm{L}$ ammonium sulfate, $0.5 \mathrm{~g} / \mathrm{L}$ potassium phosphate, $0.25 \mathrm{~g} / \mathrm{L}$ magnesium sulfate, $10 \mathrm{~g} / \mathrm{L}$ yeast extract and $10 \mathrm{~g} / \mathrm{L}$ peptone at $30{ }^{\circ} \mathrm{C}$ and $200 \mathrm{rpm}$ for $\mathrm{S}$. cerevisiae, $250 \mathrm{rpm}$ for P. stipitis and $150 \mathrm{rpm}$ for Z. mobilis in an orbital shaker for $12 \mathrm{~h}$ and centrifuged [25]. The cell concentration was inoculated at an optical density of 2 for S. cerevisiae, P. stipitis and Z. mobilis, respectively, at $600 \mathrm{~nm}$ in a spectrophotometer UV-VIS [26]. Subsequently, the cells were inoculated into $48 \mathrm{~mL}$ culture medium to start the SSF and SSSF processes.

\subsubsection{Simultaneous saccharification and fermentation (SSF)}

The SSF experiments were conducted using delignified pretreated solids of CFM in accordance with the NREL standard procedure [24]. The SSF was performed with $4 \%(\mathrm{w} / \mathrm{v})$ of delignified pretreated solids in $48 \mathrm{~mL}$ of sodium citrate buffer $50 \mathrm{mM}$ (pH 5.0), using the enzymatic kit of Cellic CTec 2 and Cellic HTec 2 with an enzyme loading of $30 \mathrm{FPU}, 75 \mathrm{CBU}$ and $130 \mathrm{IU}$ per gram of pretreated solid [15], supplemented with $1 \mathrm{~g} / \mathrm{L}$ ammonium sulfate, $0.5 \mathrm{~g} / \mathrm{L}$ potassium phosphate, $0.25 \mathrm{~g} / \mathrm{L}$ magnesium sulfate, $2 \mathrm{~g} / \mathrm{L}$ yeast extract and $1 \mathrm{~g} / \mathrm{L}$ peptone [25]. The SSF was started by adding enzymes and the strains, incubated at $30{ }^{\circ} \mathrm{C}$ in an orbital shaker at $200 \mathrm{rpm}$ for $S$. cerevisiae, $250 \mathrm{rpm}$ for $P$. stipitis and $150 \mathrm{rpm}$ for Z. mobilis. The samples were taken at $0,6,12,24,36$ and $48 \mathrm{~h}$. Ethanol and sugars concentrations were determined by means of HPLC (see Section 2.9). All determinations were performed in duplicate.

\subsubsection{Semi-simultaneous saccharification and fermentation (SSSF)}

The semi-simultaneous saccharification and fermentation was carried out for $12 \mathrm{~h}$ of presaccharification $+36 \mathrm{~h}$ of SSF process using delignified pretreated solids of CFM as substrate. The SSSF were performed with $4 \%(\mathrm{w} / \mathrm{v})$ of delignified pretreated solids in $48 \mathrm{~mL}$ of sodium citrate buffer $50 \mathrm{mM}$ ( $\mathrm{pH}$ 5.0), using the enzymatic kit of Cellic CTec 2 and Cellic HTec 2 with an enzyme loading of 30 FPU, 75 CBU and 130 IU per gram of pretreated solid [15]; in this presaccharification period, the medium temperature was maintained at $50{ }^{\circ} \mathrm{C}$. After $12 \mathrm{~h}$ of hydrolysis, the medium temperature was adjusted to $30{ }^{\circ} \mathrm{C}$ and supplemented with $1 \mathrm{~g} / \mathrm{L}$ ammonium sulfate, $0.5 \mathrm{~g} / \mathrm{L}$ potassium phosphate, $0.25 \mathrm{~g} / \mathrm{L}$ magnesium sulfate, $2 \mathrm{~g} / \mathrm{L}$ yeast extract and $1 \mathrm{~g} / \mathrm{L}$ peptone. Then, the fermentative process was started by adding the strains in an orbital shaker at $200 \mathrm{rpm}$ for $S$. cerevisiae, $250 \mathrm{rpm}$ for $P$. stipitis and $150 \mathrm{rpm}$ for Z. mobilis. The samples were taken at $0,6,12,24,36$ and $48 \mathrm{~h}$. Ethanol and sugars concentrations were determined by means of HPLC (see Section 2.9). All determinations were performed in duplicate. The ethanol yield (Equation (5)) was calculated assuming that all the potential glucose in the pretreated delignified solids was available for fermentation and that $1 \mathrm{~g}$ of glucose yielded $0.51 \mathrm{~g}$ of ethanol and $1 \mathrm{~g}$ of cellulose gave $0.9 \mathrm{~g}$ of glucose [24]. 
Ethanol yield $(\%)=\frac{[\text { ethanol }]}{[\text { glucose or xylose initial }] \cdot 0.511} \cdot 100$

where:

ethanol = final ethanol concentration $(\mathrm{g} / \mathrm{L})$;

glucose or xylose initial = initial concentration of glucose or xylose $(\mathrm{g} / \mathrm{L})$;

$0.511=$ conversion factor of glucose or xylose to ethanol.

\subsubsection{Statistical analyzes for SSF and SSSF}

Statistical significance of ethanol production was evaluated by Fisher's F-test for analysis of variance (ANOVA) and Student $t$-test, with a confidence level of $95 \%$. Statistical analyzes were performed with the aid of Statistica software.

\subsection{Analysis of samples in high performance liquid chromatography}

All the samples were centrifuged and filtered through a $0.2 \mu \mathrm{m}$ sterile membrane filter an analyzed for glucose, xylose, ethanol, HMF, furfural and acetic acid. Chromatographic separation was performed using a Metacarb $87 \mathrm{H}$ column $(300 \times 7.8 \mathrm{~mm}$, Varian, USA) under the following conditions: mobile phase $0.005 \mathrm{~mol} / \mathrm{L}$ sulfuric acid, flow rate $0.7 \mathrm{~mL} / \mathrm{min}$ and column temperature $60{ }^{\circ} \mathrm{C}$ using a Jasco chromatograph 880-PU pump (Jasco, Tokyo, Japan) equipped with a Jasco 830-IR refraction-index detector (Jasco, Tokyo, Japan) and a Jasco AS-2057 Plus auto sampler (Jasco, Tokyo, Japan).

\section{Results and discussion}

\subsection{Characterization of pretreated solids}

\subsubsection{Chemical composition after the pretreatment}

The chemical composition of untreated and pretreated solid CFM is shown in Table 2. The moisture content of untreated CFM was $6.14 \%$. A reduction between 39.48 and $78.36 \%$ in the amount of solids in pretreated CFM is observed and correlates to the increase of the operational conditions of HPCSH (Table 2).
Changes in the chemical composition of CFM in HPCSH in comparison to the untreated CFM were observed, corresponding to a cellulose increase of $32.18-59.71 \%$, hemicellulose reduction of $27.81-8.61 \%$ and lignin reduction of $25.02-2.72 \%$ (Table 2 ). These modifications are strategic for the fractionation of CFM. Gonçalves et al. [15] carried out an autohydrolysis pretreatment $\left(200{ }^{\circ} \mathrm{C}\right.$ for $50 \mathrm{~min}$ ) in CFM, that resulted in a solid yield of $76.89 \%$, cellulose increase of $40.55 \%$, hemicellulose reduction of $50.16 \%$ and lignin increase of $19.10 \%$. Recently Kim and Han [10] carried out HPCSH on rice straw $(5 \%(\mathrm{w} / \mathrm{w}))$ with sodium hydroxide at $80{ }^{\circ} \mathrm{C}$ for $1 \mathrm{~h}$, the result showed a composition of $50.6 \%$ cellulose, $21.7 \%$ hemicellulose and lignin $9.5 \%$, with the reduction in lignin of $46.88 \%$. Rawat et al. [9] carried out in poplar (Populus deltoids) the HPCSH $(2.8 \%(\mathrm{w} /$ w) with sodium hydroxide at $94{ }^{\circ} \mathrm{C}$ for $1 \mathrm{~h}$ ) having as result an increase in cellulose of $26.15 \%$ and hemicellulose of $14.20 \%$, with a reduction in lignin of $12.70 \%$. Similar results were obtained in this work for cellulose and lignin, but a reduction of hemicellulose was obtained. According to Ballesteros et al. [27] increased hemicellulose degradation in agricultural waste occurs at high temperatures and high residence times, therefore, higher operating conditions will provide a higher reduction of hemicellulose. The reduction of lignin increases linearly with an increase in the conditions of the pretreatment, taking into account the alkali concentration, temperature and reaction time [10].

\subsubsection{Scanning electron microscopy (SEM)}

The use of SEM permits a detailed visualization of morphological and structural changes in CFM after the proposed thermochemical pretreatment. The SEM micrographs of CFM untreated and after $\mathrm{HPCSH}\left(2.5 \%(\mathrm{v} / \mathrm{v})\right.$ sodium hydroxide at $180^{\circ} \mathrm{C}$ for $\left.30 \mathrm{~min}\right)$ are shown in Fig. 3A-B.

The SEM images indicate that untreated FCM had intact epidermis, lumen and vascular bundles (Fig. 3A). The HPCSH developed cracks that were heterogeneous and scattered throughout the biomass. Development of these cracks can increase the surface area to facilitate the disruption of lignocellulose, a prerequisite for EH of cellulose and hemicellulose (Fig. 3B). Similar results were reported by Kim and Han [10] and Rawat et al. [9] on rice straw and poplar wood pretreated by HPCSH, respectively.

\subsubsection{X-ray diffraction analysis}

The analysis of X-ray diffraction for crystallinity index determination were carried out in untreated and pretreated CFM aiming

Table 2

Composition on the solid phase and yield of pretreated CFM.

\begin{tabular}{|c|c|c|c|c|c|}
\hline \multirow[t]{2}{*}{ Assay } & \multicolumn{5}{|c|}{ Solid phase (\%) } \\
\hline & Solid yield & Cellulose & Hemicellulose & Klason lignin & Ash \\
\hline Untreated & $100 \pm 0.00$ & $32.18 \pm 0.12$ & $27.81 \pm 0.74$ & $25.02 \pm 0.21$ & $3.31 \pm 0.32$ \\
\hline 1 & $60.52 \pm 1.86$ & $41.32 \pm 0.15$ & $15.79 \pm 0.22$ & $22.95 \pm 0.10$ & $4.36 \pm 0.12$ \\
\hline 2 & $54.53 \pm 0.53$ & $46.25 \pm 0.81$ & $12.49 \pm 0.85$ & $20.20 \pm 0.23$ & $5.38 \pm 0.82$ \\
\hline 3 & $48.36 \pm 1.88$ & $49.31 \pm 0.84$ & $12.88 \pm 0.17$ & $10.36 \pm 0.21$ & $7.90 \pm 0.21$ \\
\hline 4 & $48.93 \pm 0.42$ & $51.61 \pm 0.15$ & $14.72 \pm 0.43$ & $14.14 \pm 0.19$ & $7.10 \pm 0.39$ \\
\hline 5 & $54.36 \pm 0.77$ & $48.78 \pm 0.36$ & $14.79 \pm 0.80$ & $15.56 \pm 0.13$ & $6.96 \pm 0.17$ \\
\hline 6 & $43.14 \pm 0.92$ & $58.72 \pm 1.05$ & $13.71 \pm 0.43$ & $11.76 \pm 0.33$ & $7.60 \pm 0.31$ \\
\hline 7 & $21.64 \pm 0.39$ & $71.35 \pm 1.08$ & $8.61 \pm 0.36$ & $2.72 \pm 0.35$ & $9.20 \pm 0.21$ \\
\hline 8 & $43.09 \pm 1.06$ & $59.71 \pm 0.27$ & $11.23 \pm 0.43$ & $5.06 \pm 0.84$ & $8.50 \pm 0.16$ \\
\hline 9 & $43.14 \pm 0.39$ & $56.39 \pm 0.02$ & $12.26 \pm 0.21$ & $12.00 \pm 0.11$ & $8.30 \pm 0.11$ \\
\hline 10 & $42.09 \pm 0.28$ & $56.44 \pm 0.30$ & $12.59 \pm 0.88$ & $11.72 \pm 0.10$ & $8.29 \pm 0.37$ \\
\hline 11 & $48.67 \pm 0.13$ & $54.31 \pm 0.31$ & $12.85 \pm 0.18$ & $12.62 \pm 0.11$ & $8.88 \pm 0.12$ \\
\hline 12 & $41.53 \pm 0.60$ & $58.76 \pm 0.31$ & $12.69 \pm 0.16$ & $10.34 \pm 0.33$ & $8.11 \pm 0.04$ \\
\hline 13 & $45.58 \pm 1.36$ & $48.19 \pm 0.17$ & $13.02 \pm 0.67$ & $12.75 \pm 0.21$ & $7.35 \pm 0.11$ \\
\hline 14 & $32.11 \pm 0.15$ & $56.70 \pm 0.54$ & $10.03 \pm 0.23$ & $7.84 \pm 0.14$ & $8.53 \pm 0.17$ \\
\hline 15 & $45.87 \pm 0.13$ & $53.85 \pm 0.58$ & $12.30 \pm 0.14$ & $13.60 \pm 0.28$ & $7.07 \pm 0.19$ \\
\hline 16 & $41.89 \pm 0.63$ & $57.02 \pm 0.33$ & $10.10 \pm 0.32$ & $9.44 \pm 0.11$ & $8.15 \pm 0.26$ \\
\hline
\end{tabular}


A

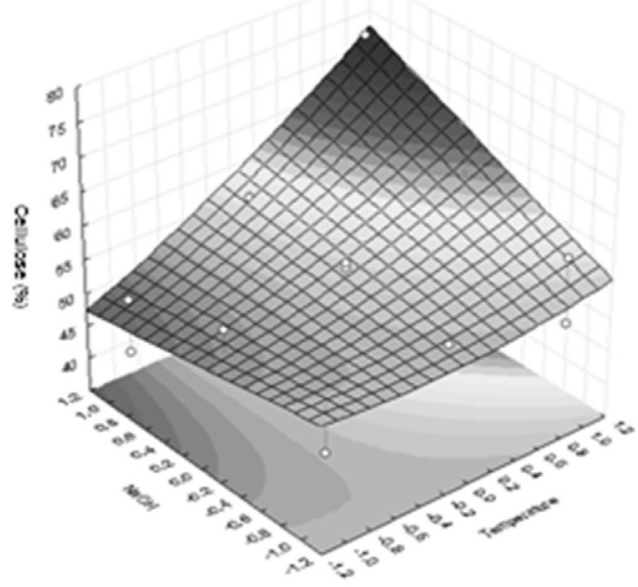

B

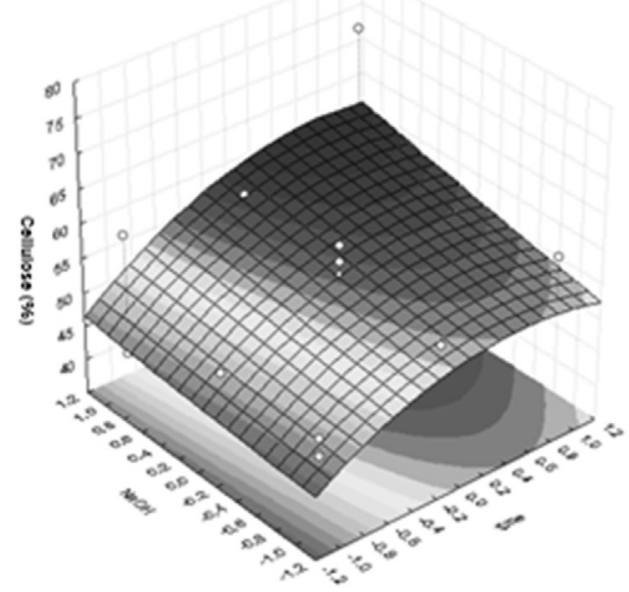

C

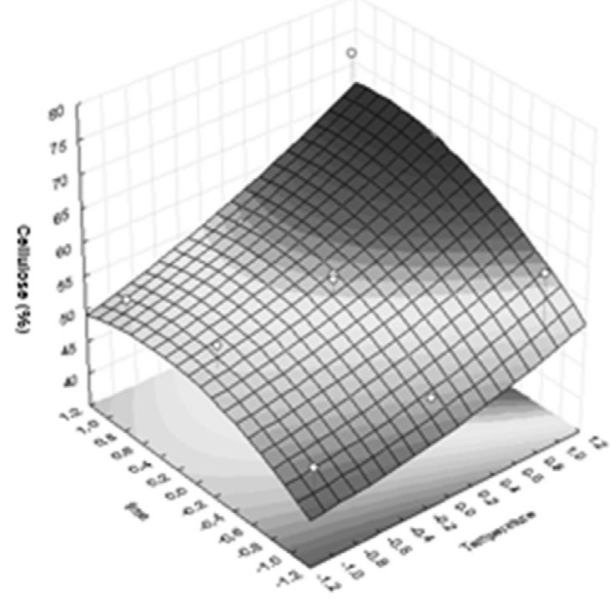

to analyze the crystalline structure.

Untreated CFM possesses a crystallinity index of $34.34 \%$, while the CFM pretreated by HPCSH $(2.5 \%(\mathrm{v} / \mathrm{v})$ sodium hydroxide at $180{ }^{\circ} \mathrm{C}$ for $30 \mathrm{~min}$ ) presents a value of $56.38 \%$ (Fig. 3C). The results showed an increase in the crystallinity index of pretreated CFM in relation to untreated CFM. According to Pu et al. [28], this effect can be explained by the removal of amorphous cellulose and hemicellulose that causes an increase in the crystallinity.

\subsubsection{Statistical analysis of pretreatment processing}

The experimental design was conducted to determine the variables that affect the pretreatment of CFM and influence in cellulose content of the pretreated material. The conditions used in the experimental design were temperature $\left(160,180\right.$ and $\left.200^{\circ} \mathrm{C}\right)$, time $(10,30$ and $50 \mathrm{~min}$ ) and the concentration of sodium hydroxide (1.0, 2.5 and $4.0 \%)$.

Multiple regression analysis and analysis of variance (ANOVA) of the experimental data were performed for the mathematical model fitting. The models in terms of normalized values (Table 1) expressed in Equation (6) represent the cellulose CFM content in HPCSH, as function of temperature $\left(X_{1}\right)$, time $\left(X_{2}\right)$ and concentration of sodium hydroxide $\left(X_{3}\right)$.

$$
\begin{aligned}
\% \text { Cellulose }= & 55.70+5.65 * \text { Temperature }+4.64 * \text { time } \\
& +2.15 * \mathrm{NaOH}+4.10 \text { Temperature } * \mathrm{NaOH} \\
& \left(R^{2}=0.9566 ; \quad R_{a d j}=0.8916\right)
\end{aligned}
$$

Response surfaces were drawn as three-dimensional plots of the second-order polynomial models (Equation (6)) as a function of the two most strongly influencing variables. Cellulose yield was plotted as a function of temperature, time and sodium hydroxide (Fig. 1) being demonstrated that the increase in cellulose yield is correlated with increases in temperature, time and concentration of sodium hydroxide during the HPCSH.

Results of ANOVA listed in Equation (6) revealed that the second-order polynomial models adequately represent the responses of cellulose yield with coefficients of determination $R^{2}$, which indicates that $95.66 \%$ of the variability of response might be explained by the model. These values are in accordance with the adjusted coefficient of determination $R^{2}$ adj $=0.8916$.

According to ANOVA results for cellulose yield in CFM pretreated by HPCSH (Table 4), the linear $X_{1}, X_{2}$ and $X_{3}$ and interaction $X_{1} X_{3}$ terms have a significant effect on cellulose yield responses with pvalue under a significance level of $\alpha=0.05$. These effects can be visualized in the standardized Pareto charts (Fig. 2A). It is observed that the variables of temperature, time, concentration of sodium hydroxide and temperature-concentration of sodium hydroxide interaction are important in a confidence level of $95 \%$ on the cellulose yield and the effect of temperature, time and concentration of sodium hydroxide are positive, when increased from lower to higher values (Fig. 1). Furthermore, the predicted values versus observed values by the application of the model for multiple regression are shown in Fig. 2B and evidence the good quality of fit.

\subsection{Characterization of the liquor}

\subsubsection{Liquor composition}

The liquor separated by filtration of the solid phase from the solution of the HPCSH treated CFM, according to the conditions shown in Table 1, possesses $\mathrm{pH}$ variations during HPCSH between 9.3 and 13.6 (Table 3). This increase in pH value is correlated with increase in the operating conditions of the pretreatment (temperature, time and concentration of sodium hydroxide).

A linear correlation is observed between the increase in the $\mathrm{pH}$
Fig. 1. Response surface and contour plot of pretreated CFM. A) Cellulose variation as a function of temperature and sodium hydroxide; B) Cellulose variation as a function of time and sodium hydroxide; C) Glucose variation as a function of time and temperature. 


\section{A}

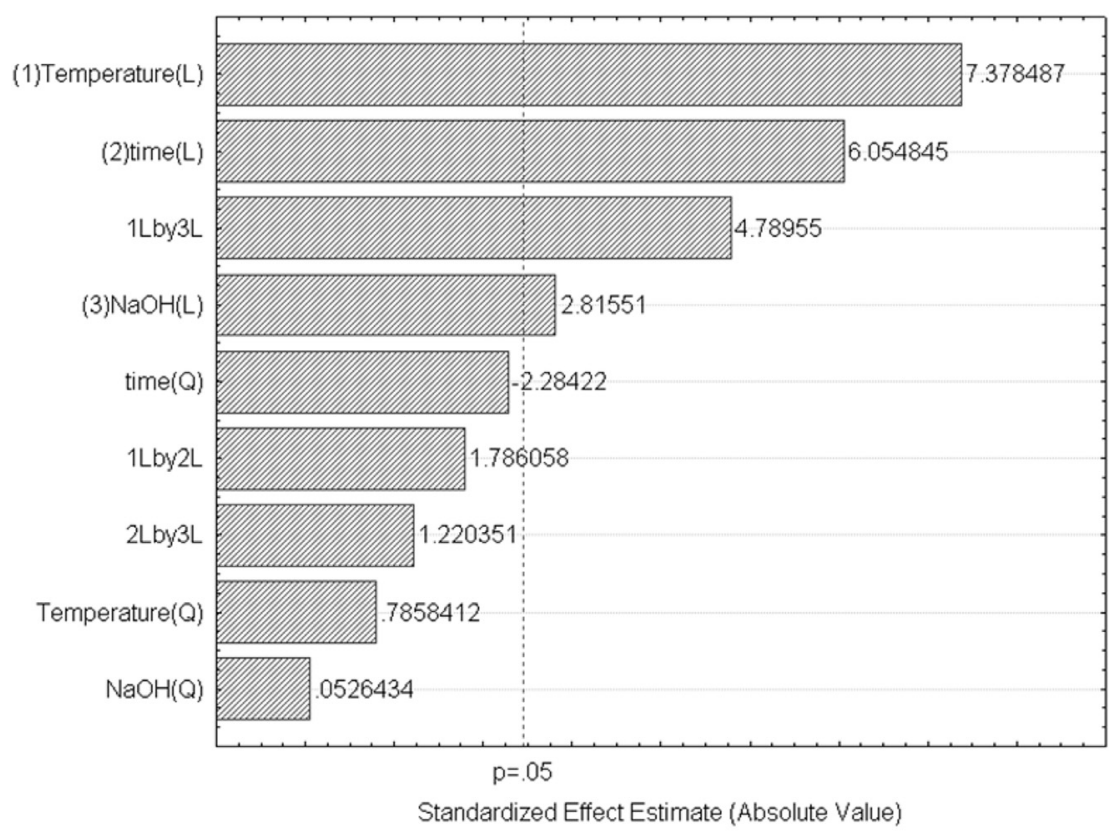

B

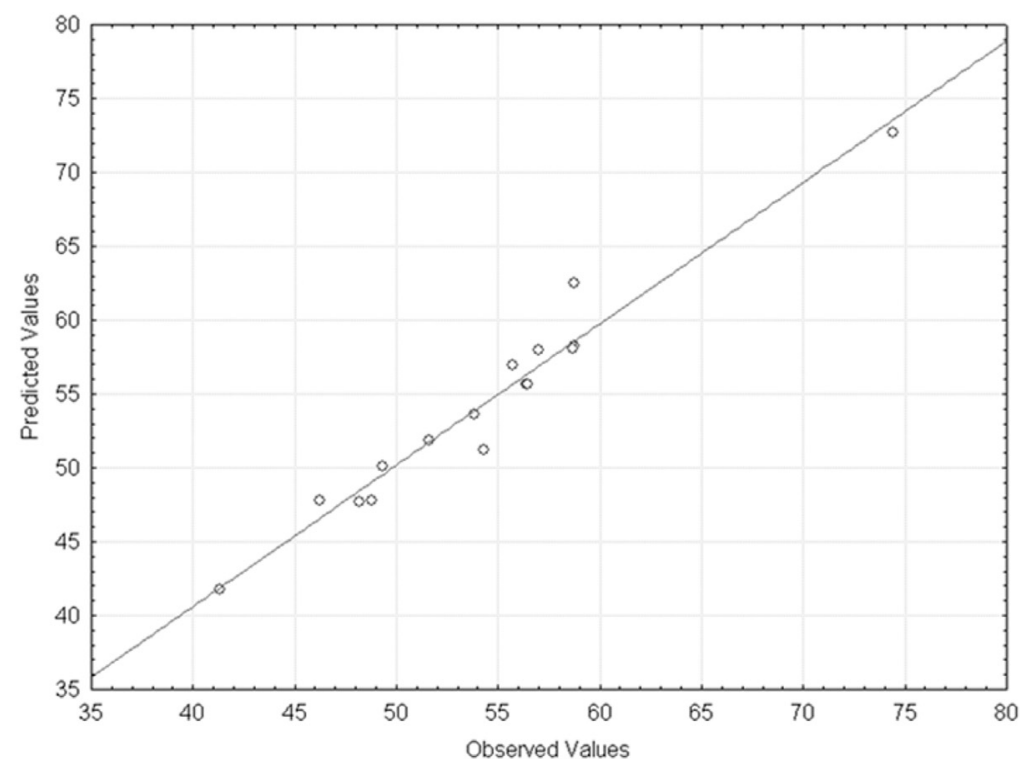

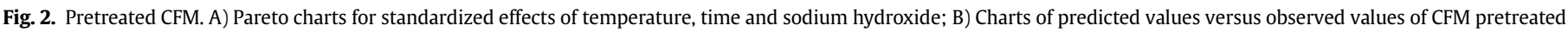
by HPCSH related to cellulose (\%).

and the increase in the concentrations of cellulose, hemicellulose, HMF, furfural and total phenolic compounds in the liquors. Furthermore, the pretreatment of CFM by PHCHS allowed for the obtention of concentrations of glucose, hemicellulose, HMF and furfural in the liquors as high as 4.09, 23.09, 0.21 and $0.88 \mathrm{~g} / \mathrm{L}$, respectively (Table 3 ). Monosaccharides, oligosaccharides, acetic acid, total phenolic compounds and lignin present in the liquors can be used in biotechnological and technological processes and in a biorefinery concept.

\subsubsection{Total phenolic compounds in the liquid fraction}

The liquors of CFM pretreated by HPCSH showed between 7.49 and $17.52 \mathrm{~g} / \mathrm{L}$ of total phenolic compounds (total phenolic compounds between 74.9 and $175.2 \mathrm{mg} / \mathrm{g}$ of LCM dry) (Table 3). Faustino et al. [29] analyzed the black liquor of E. globulus in kraft pretreatment and the obtained phenolic compounds concentration was between 91.6 and $293.5 \mathrm{mg} / \mathrm{g}$ of LCM dry weight, values that are within the range of results reported in this work. 


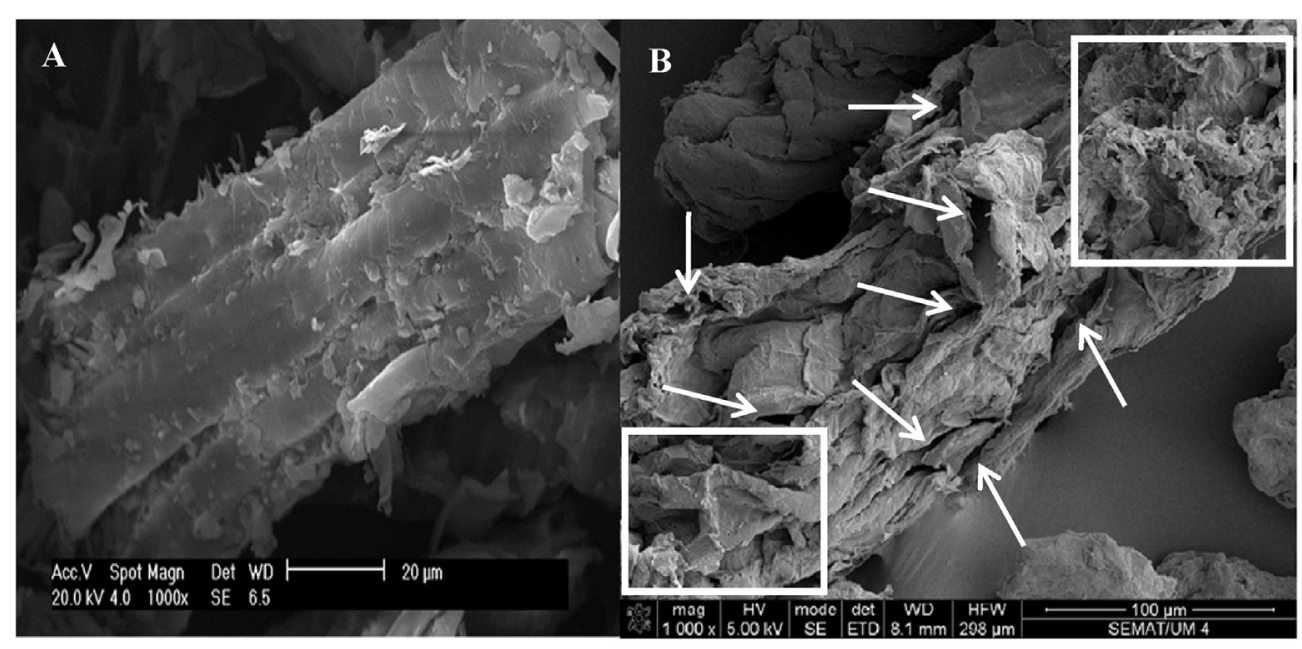

C Untreated $\quad$ Coconut fibre mature pretreated

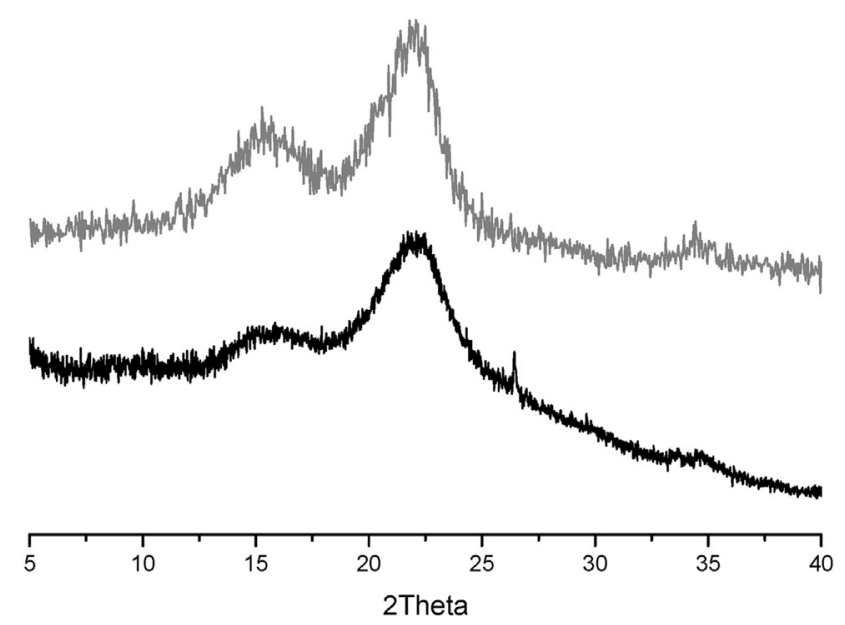

Fig. 3. CFM. A) SEM of CFM untreated; B) SEM of CFM pretreated by HPCSH $(2.5 \%(\mathrm{v} / \mathrm{v}))$ sodium hydroxide at $180{ }^{\circ} \mathrm{C}$ for 30 min). High porosity area, matrix separation and exposition fibres (white square); C) DRX of CFM untreated and pretreated.

Table 3

Composition of the liquid phase of pretreated CFM.

\begin{tabular}{|c|c|c|c|c|c|c|c|c|c|}
\hline \multirow[t]{2}{*}{ Assay } & \multirow[t]{2}{*}{$\mathrm{pH}$} & \multirow[t]{2}{*}{ Solubilized material (\%) } & \multirow[t]{2}{*}{ Lignin recovered (\%) } & \multicolumn{6}{|l|}{ Liquid phase (g/L) } \\
\hline & & & & Lignin recovered & Phenolic compounds & Glucose & Hemicellulose & HMF & Furfural \\
\hline 1 & 11.6 & 39.48 & $85.27 \pm 0.44$ & $8.54 \pm 0.09$ & $7.49 \pm 0.21$ & 1.36 & 16.24 & 0.14 & 0.55 \\
\hline 2 & 13.2 & 45.47 & $84.64 \pm 0.50$ & $9.84 \pm 0.04$ & $9.02 \pm 0.07$ & 0.89 & 18.69 & 0.17 & 0.70 \\
\hline 3 & 13.3 & 51.64 & $88.35 \pm 0.26$ & $15.91 \pm 0.13$ & $11.18 \pm 0.03$ & 1.66 & 19.21 & 0.17 & 0.68 \\
\hline 4 & 9.3 & 51.07 & $86.57 \pm 0.81$ & $16.01 \pm 0.11$ & $12.52 \pm 0.01$ & 1.88 & 18.34 & 0.15 & 0.60 \\
\hline 5 & 9.9 & 45.65 & $88.92 \pm 1.28$ & $13.26 \pm 0.01$ & $11.86 \pm 0.18$ & 1.61 & 17.60 & 0.15 & 0.60 \\
\hline 6 & 12.9 & 56.86 & $89.31 \pm 0.16$ & $15.69 \pm 0.04$ & $12.42 \pm 0.45$ & 2.57 & 19.49 & 0.16 & 0.65 \\
\hline 7 & 13.1 & 78.37 & $87.88 \pm 0.68$ & $19.32 \pm 0.14$ & $17.52 \pm 0.07$ & 4.09 & 23.09 & 0.21 & 0.88 \\
\hline 8 & 13.0 & 56.91 & $88.10 \pm 0.14$ & $18.11 \pm 0.08$ & $17.09 \pm 0.20$ & 2.57 & 20.44 & 0.18 & 0.76 \\
\hline 9 & 13.0 & 56.86 & $88.79 \pm 0.49$ & $15.86 \pm 0.13$ & $14.63 \pm 0.02$ & 2.35 & 20.18 & 0.17 & 0.71 \\
\hline 10 & 13.0 & 57.92 & $88.66 \pm 0.41$ & $16.03 \pm 0.04$ & $14.31 \pm 0.02$ & 2.35 & 20.04 & 0.17 & 0.70 \\
\hline 11 & 13.0 & 51.34 & $88.14 \pm 1.00$ & $14.98 \pm 0.13$ & $12.17 \pm 0.10$ & 2.14 & 19.19 & 0.17 & 0.69 \\
\hline 12 & 12.7 & 58.47 & $89.90 \pm 0.50$ & $16.43 \pm 0.10$ & $14.50 \pm 0.27$ & 2.57 & 20.06 & 0.17 & 0.69 \\
\hline 13 & 13.3 & 54.42 & $88.40 \pm 0.71$ & $15.28 \pm 0.13$ & $14.39 \pm 0.02$ & 1.55 & 19.47 & 0.16 & 0.68 \\
\hline 14 & 12.9 & 67.89 & $91.10 \pm 1.45$ & $18.45 \pm 0.13$ & $16.07 \pm 0.03$ & 2.28 & 21.88 & 0.19 & 0.82 \\
\hline 15 & 9.6 & 54.13 & $85.81 \pm 0.83$ & $14.86 \pm 0.11$ & $11.55 \pm 0.05$ & 2.10 & 19.73 & 0.17 & 0.71 \\
\hline 16 & 13.6 & 58.11 & $85.12 \pm 0.51$ & $15.50 \pm 0.13$ & $11.49 \pm 0.06$ & 2.41 & 20.99 & 0.19 & 0.81 \\
\hline
\end{tabular}


Table 4

Analysis of variance (ANOVA) for glucose as a function of temperature $\left(x_{1}\right)$, time $\left(x_{2}\right)$ and sodium hydroxide $\left(x_{3}\right)$.

\begin{tabular}{lcrccl}
\hline Source & Sum of squares & d.f & Mean square & $F$-value & $p$-value \\
\hline$x_{1}$ & 320.12 & 1 & 320.12 & 54.4420 & $0.00031^{*}$ \\
$x_{1}^{2}$ & 3.63 & 1 & 3.63 & 0.61757 & 0.46185 \\
$x_{2}$ & 215.57 & 1 & 215.57 & 36.6611 & $0.00092^{*}$ \\
$x_{2}^{2}$ & 30.680 & 1 & 30.687 & 24544.6 & 0.06243 \\
$x_{3}$ & 46.61 & 1 & 46.61 & 7.9270 & $0.03053^{*}$ \\
$x_{3}^{2}$ & 0.0163 & 1 & 0.0163 & 0.0027 & 0.95972 \\
$x_{1} x_{2}$ & 18.7578 & 1 & 18.7578 & 3.1900 & 0.12433 \\
$x_{1} x_{3}$ & 134.890 & 1 & 134.8903 & 22.9397 & $0.00303^{*}$ \\
$x_{2} x_{3}$ & 8.7571 & 1 & 8.7571 & 1.4892 & 0.26811 \\
Pure error & 35.2811 & 6 & 5.8801 & & \\
Total & 814.2037 & 15 & & & \\
\hline
\end{tabular}

d.f., degree of freedom, ${ }^{*}$ significant, Fcalculated: 14.72, Ftabulated: 4.10 .

\subsubsection{Acid precipitation of lignin present in the liquors}

Acid precipitation is the most common method for recovering lignin from black liquor [12]. In this context, liquors obtained from the pretreatment of CFM were precipitated by the addition of acid, resulting in values between 8.54 and $19.32 \mathrm{~g} / \mathrm{L}$ of lignin, with a lignin recovery yield of $91.1 \%$ (in relation to the total lignin present in the liquor). In comparison, Egüés et al. [11] carried out the recovery of lignin of corn residues (contains $17.18 \%$ of Klason lignin) pretreated by $\mathrm{HPCSH}\left(160{ }^{\circ} \mathrm{C}\right.$ and $75 \mathrm{~min}$, solid/liquid ratio of $1: 20$ and shall the solubilization of LCM of 39.75\%) resulting in $2.5 \mathrm{~g} / \mathrm{L}$ of lignin. These results demonstrate the efficiency of the method for lignin recovery used in this work.

\subsubsection{FTIR of lignin obtained by precipitation}

The analyzes were carried out by infrared spectroscopy with the purpose of obtaining information from chemical groups present in the lignin [30]. The FTIR spectra in the region between 500 and $4000 \mathrm{~cm}^{-1}$ of standard lignin and recovered lignin of liquor from CFM pretreated by HPCSH (2.5\% (v/v) sodium hydroxide at $180{ }^{\circ} \mathrm{C}$ for $30 \mathrm{~min}$ ) are shown in Fig. 4.

The spectra are dominated by a wide band at $3396-3381 \mathrm{~cm}^{-1}$ due to aliphatic and phenolic $\mathrm{OH}$-groups, followed by bands for $\mathrm{CH}$ stretching in methyl and methylene groups $\left(2962-2874 \mathrm{~cm}^{-1}\right)$, the bands at 1604, 1516 and $1495 \mathrm{~cm}^{-1}$ assigned to aromatic skeletal vibrations, $1454 \mathrm{~cm}^{-1}$ assigned to $\mathrm{CH}$ deformations and aromatic ring vibrations, $1440 \mathrm{~cm}^{-1}$ assigned to aromatic skeletal vibrations, $1331 \mathrm{~cm}^{-1}$ assigned to syringyl ring breathing with CO stretching, $1284 \mathrm{~cm}^{-1}$ assigned to guaiacyl ring breathing with CO stretching and $1039 \mathrm{~cm}^{-1}$ assigned to aromatic $\mathrm{CH}$ guaiacyl type and $\mathrm{CH}$ deformation of primary alcohol. Besides these, there are bands observed at 1201, 1070,753, 667 and $570 \mathrm{~cm}^{-1}$. The absence of a peak at $1739 \mathrm{~cm}^{-1}$ are assigned to CO stretching of unconjugated ketone, carbonyl and ester groups, indicating the presence of hydroxycinnamates, such as $p$-coumarate and ferulate [31].

The peaks at wavelength of $1170-1164 \mathrm{~cm}^{-1}$ were not observed in the spectra of lignins. According to Tan et al. [32], the absence of this peak indicates the absence of sulfur in the lignin and becomes an important characteristic, because sulfur in the lignin is a contaminant and interferes with its use.

\subsubsection{Thermogravimetric analysis (TGA) of lignin obtained by precipitation}

The thermal stability of the recovered lignin of liquor from CFM pretreated by PHCHS (2.5\% (v/v) sodium hydroxide at $180{ }^{\circ} \mathrm{C}$ for $30 \mathrm{~min}$ ) was investigated by TGA and is shown in Fig. 4B. The lignin degradation profiles of the sample of standard lignin and the sample of recovered lignin of liquor from CFM pretreated by PHCHS were similar. The residual weight at $600{ }^{\circ} \mathrm{C}$ of recovered lignin was $55.68 \%$, whereas that of the standard lignin was $56.71 \%$. Overall, the thermal decomposition behaviour of the lignin samples can be divided into three stages. The first stage $\left(25-150{ }^{\circ} \mathrm{C}\right)$ involves the dehydration of lignin due to the absorbed water in lignin. The lignin sample contained a certain amount of bound water whose evaporation occurred at temperatures higher than $100{ }^{\circ} \mathrm{C}$, indicating the strong interaction between water molecules and the hydroxyl groups in lignin samples. The next stage, occurred up to $350{ }^{\circ} \mathrm{C}$, involves the fragmentations of internal linkages between lignin units. The major products in this stage were coke, organic acid and phenolic compounds together with gas products [33]. In the last stage (over $350^{\circ} \mathrm{C}$ ), pyrolytic degradation of lignin, decomposition and condensation of the aromatic rings occurred [34].

\subsection{Susceptibility to the enzymatic hydrolysis}

Conversions of CFM pretreated by HPCSH (2.5\% (v/v) sodium hydroxide at $180{ }^{\circ} \mathrm{C}$ for $30 \mathrm{~min}$ ) in glucose was $90.72 \%$ at $96 \mathrm{~h}$ of $\mathrm{EH}$, being $88.90 \%$ at $72 \mathrm{~h}$ and $85.35 \%$ at $48 \mathrm{~h}$ of $\mathrm{EH}$ (Fig. $5 \mathrm{~A}$ ).

These results demonstrate the accessibility of CFM to the enzymatic attack. In comparison, for the CFM pretreated by autohydrolysis $\left(200{ }^{\circ} \mathrm{C}\right.$ for $\left.50 \mathrm{~min}\right)$ the conversion in glucose by $\mathrm{EH}$ at $96 \mathrm{~h}$ was $84.10 \%$ [15]. The minor conversion of CFM pretreated by autohydrolysis in glucose may have been influenced by the higher content of lignin in the CFM (29.80\% of lignin), when compared to the CFM pretreated by HPCSH (11.72\% of lignin) [15]. The EH of poplar wood treated by HPCSH $(2.8 \%(\mathrm{w} / \mathrm{w})$ sodium hydroxide at $94^{\circ} \mathrm{C}$ for $1 \mathrm{~h}$ ) resulted in a conversion into glucose at $48 \mathrm{~h}$ of $41.5 \%$ [9]. The conversion to glucose during the EH of Eucalyptus grandis pretreated by steam explosion catalyzed by sodium hydroxide ( $7 \%$ (w/w) of sodium hydroxide at $210^{\circ} \mathrm{C}$ for $9 \mathrm{~min}$ ) was $65.55 \%$ in $72 \mathrm{~h}$ [7]. The EH of rice straw after HPCSH $(5 \%(w / w)$ sodium hydroxide at $80{ }^{\circ} \mathrm{C}$ for $1 \mathrm{~h}$ ) resulted in a conversion into glucose of $78.7 \%$ at $72 \mathrm{~h}[10]$.

Looking at the maximum initial hydrolysis rate (productivity of glucose) $(d G / d t)$, that occurs in the first $12 \mathrm{~h}$ (the slope of glucose concentration vs time) shown in Fig. 5B, the initial hydrolysis rate of CFM was $1.27 \mathrm{~g} /(\mathrm{L} \mathrm{h})$ (Fig. 5B). Gonçalves et al. [15] reported the initial hydrolysis rate of autohydrolysis pretreated CFM as $0.82 \mathrm{~g} /$ (L h) using $30 \mathrm{FPU} / \mathrm{g}$ of LCM. In comparison, Ruiz et al. [35] reported the initial hydrolysis rate of wheat straw pretreated by autohydrolysis as $0.47 \mathrm{~g} /(\mathrm{L} \mathrm{h})$ using $30 \mathrm{FPU} / \mathrm{g}$ of cellulose. Rawat et al. [9] studied the initial hydrolysis rate of poplar wood using HPCSH and obtained $1.67 \mathrm{~g} /(\mathrm{L} \mathrm{h})$ for $15 \mathrm{FPU} / \mathrm{g}$ of cellulose. These results demonstrate the susceptibility of CFM pretreated by PHCHS to the enzymatic attack.

\subsection{Fermentative process for bioethanol production}

SSF and SSSF strategies were carried out using S. cerevisiae PE2, P. stipitis Y7124, Z. mobilis B14023 on CFM pretreated by HPCSH $\left(2.5 \%(\mathrm{v} / \mathrm{v})\right.$ sodium hydroxide at $180^{\circ} \mathrm{C}$ for $\left.30 \mathrm{~min}\right)$ as raw material. According to Shen and Agblevor [14], the performance of fermentative strategies can be assessed by two indicators: yield and volumetric productivity of ethanol.

\subsubsection{Simultaneous saccharification and fermentation (SSF) and semi-simultaneous saccharification and fermentation (SSSF)}

The SSF bioethanol production results by $S$. cerevisiae, $P$. stipitis and $Z$. mobilis are shown in Fig. $6 \mathrm{~A}-\mathrm{C}$, respectively. The results of this study indicate that glucose from EH could be fermented to 

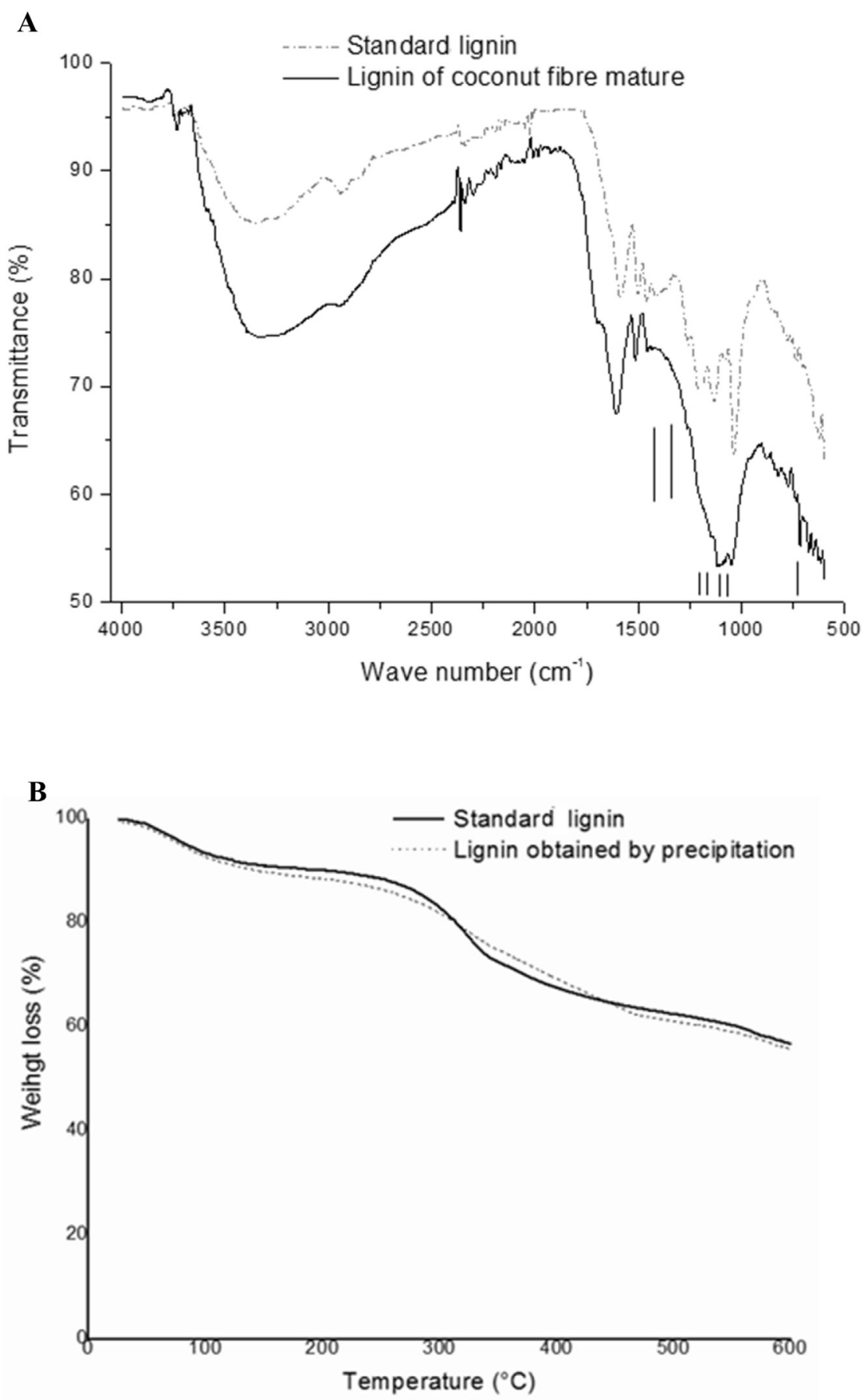

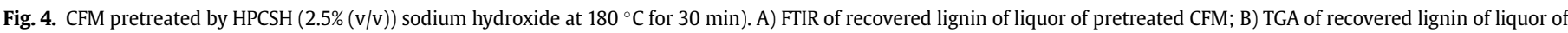
pretreated CFM.

ethanol by S. cerevisiae, P. stipitis and Z. mobilis, the kinetic profiles having a similar pattern for glucose, with rapid glucose consumption during the initial $24 \mathrm{~h}$. The corresponding production of ethanol in SSF by S. cerevisiae and Z. mobilis were $10.91 \mathrm{~g} / \mathrm{L}$ and $10.96 \mathrm{~g} / \mathrm{L}$, being the SSF process completed after $48 \mathrm{~h}$ (Fig. 6 and Table 5). The ethanol yield for P. stipitis was $87.44 \%$, corresponding to a volumetric productivity of ethanol of $0.23 \mathrm{~g} /(\mathrm{L} \mathrm{h})$ in $48 \mathrm{~h}$, while for S. cerevisiae and Z. mobilis the ethanol yield were $85.31 \%$ and $84.56 \%$, respectively. The S. cerevisiae and Z. mobilis presented volumetric productivity of ethanol of $0.30 \mathrm{~g} /(\mathrm{L} \mathrm{h})$ at $36 \mathrm{~h}$ (Table 5). The three microorganisms proved to be suitable for fermenting sugars to ethanol in SSF strategy.

In a recent work, Chaudhary et al. [36] produced bioethanol through of a sequential alkaline and acid pretreatment using Kans Grass biomass as substrate and $P$. stipitis as microorganism, reporting a productivity of $0.22 \mathrm{~g} /(\mathrm{L} \mathrm{h})$. Vaithanomsat et al. [37] studied the efficiency in the bioethanol production using SSF process with $S$. cerevisiae and coconut husk pretreated with sodium 

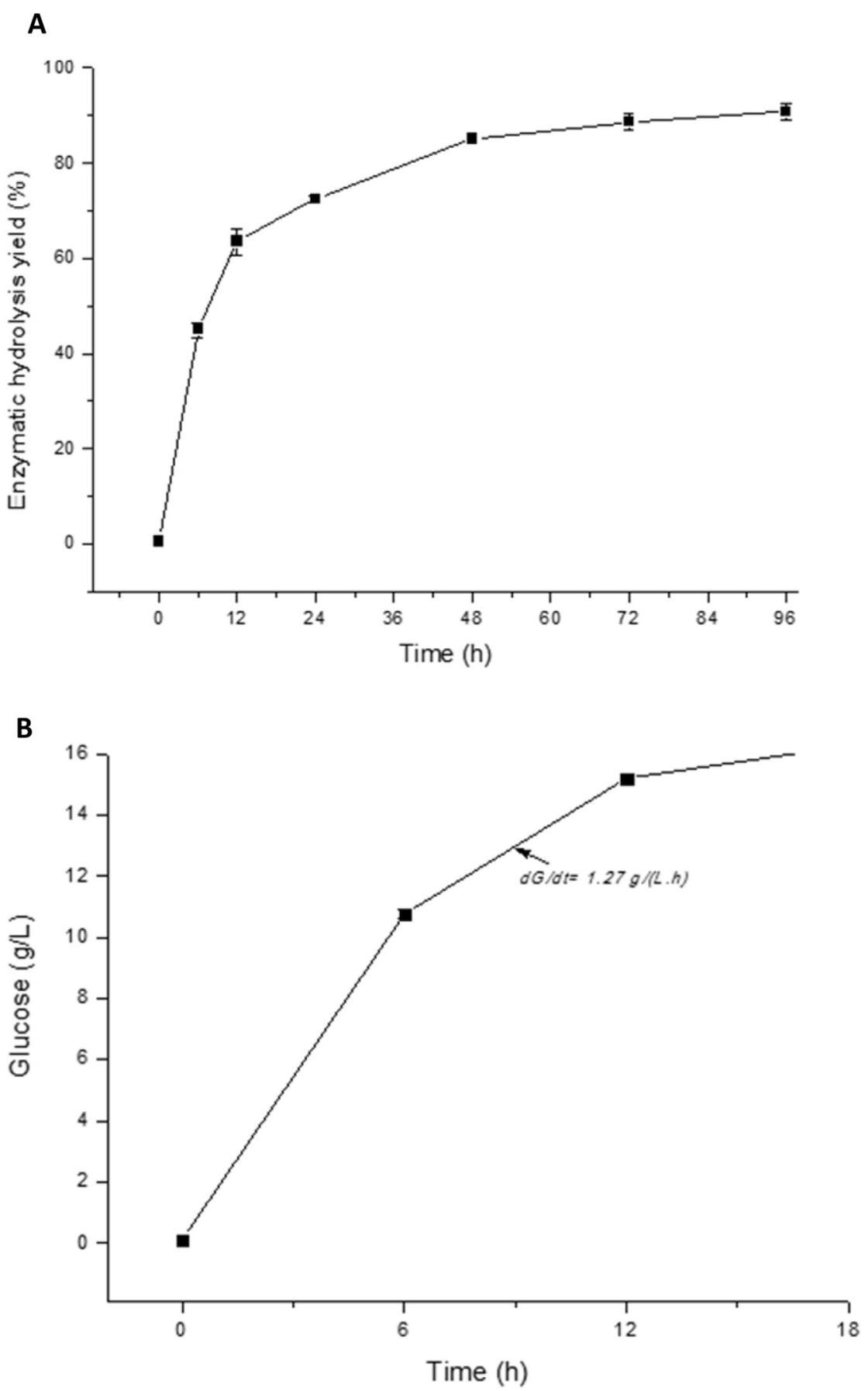

Fig. 5. EH of CFM pretreated by $\operatorname{HPCSH}(2.5 \%(\mathrm{v} / \mathrm{v}))$ sodium hydroxide at $180{ }^{\circ} \mathrm{C}$ for $\left.30 \mathrm{~min}\right)$. A) Conversion in glucose (\%); B) Initial hydrolysis rate at $12 \mathrm{~h}$.

hydroxide as raw material and reported a yield of ethanol of $85 \%$. Gonçalves et al. [15] reported the ethanol production by S. cerevisiae, $P$. stipitis and Z. mobilis in SSF using autohydrolyzed CFM, producing ethanol with a concentration of $7.44 \mathrm{~g} / \mathrm{L}, 8.47 \mathrm{~g} / \mathrm{L}$ and $7.30 \mathrm{~g} / \mathrm{L}$ and ethanol yield of $86.90 \%, 84.19 \%$ and $85.26 \%$, respectively. These results are in agreement with those reported in this work.

The SSSF strategy had a similar pattern for glucose concentration during the initial $12 \mathrm{~h}$ and a gradual decrease with time (Fig. 6A-C). The corresponding production of ethanol in SSSF by
S. cerevisiae, P. stipitis and Z. mobilis were $11.65 \mathrm{~g} / \mathrm{L}, 11.29 \mathrm{~g} / \mathrm{L}$ and $11.64 \mathrm{~g} / \mathrm{L}$, being the SSSF process completed after $48 \mathrm{~h}$, respectively (Fig. 6 and Table 5). The ethanol yield for P. stipitis was $90.18 \%$, corresponding to a volumetric productivity of ethanol of $0.24 \mathrm{~g} /$ $(\mathrm{L} \mathrm{h})$, in $48 \mathrm{~h}$, while for $S$. cerevisiae and $Z$. mobilis the obtained values were $91.17 \%, 91.03 \%$ and $0.32 \mathrm{~g} /(\mathrm{L} \mathrm{h}), 0.32 \mathrm{~g} /(\mathrm{L} \mathrm{h})$ for ethanol yield and volumetric productivity, in $36 \mathrm{~h}$, respectively (Table 5). The three microorganisms proved to be suitable for fermenting sugars to ethanol in SSSF strategy. In a recent work, Franco et al. [38] carried out the SSSF process ( $24 \mathrm{~h}$ of presaccharification and 

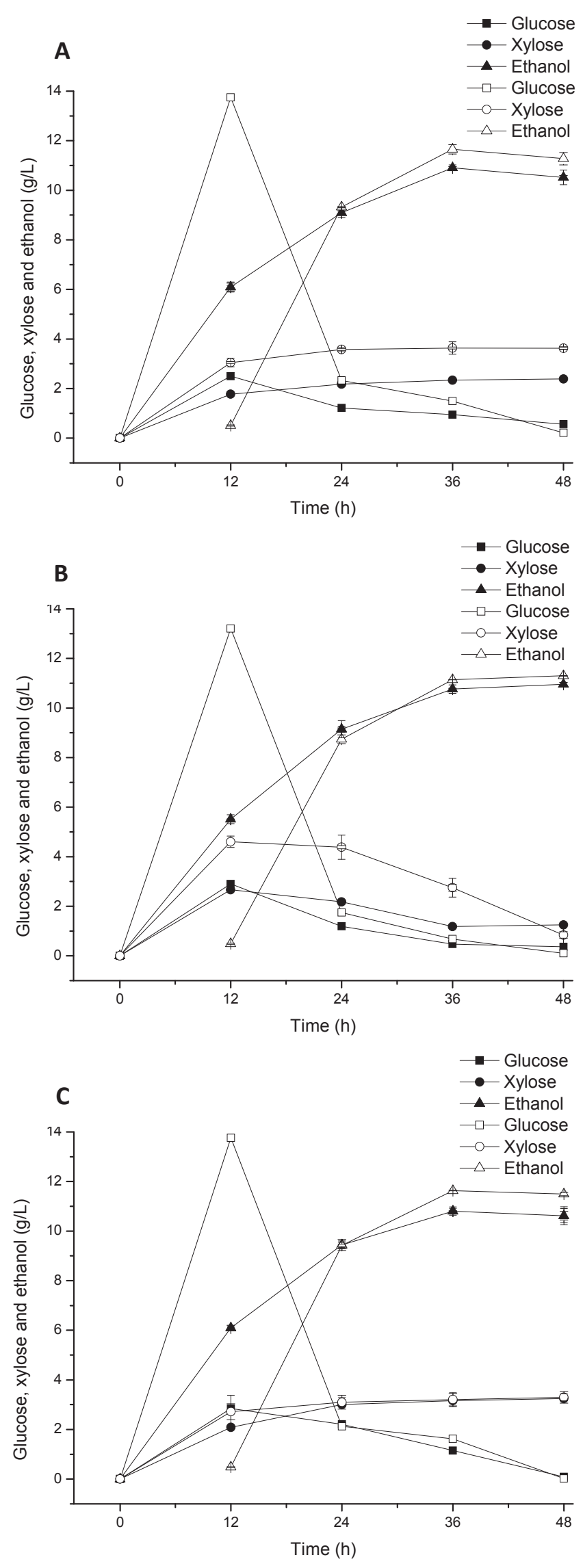

$24 \mathrm{~h}$ of SSF) using delignified Pinus radiata and S. cerevisiae, resulting in the production of $15.5 \mathrm{~g} / \mathrm{L}$ of ethanol with a yield of 90.0\%. Furthermore, Gonçalves et al. [15] reported ethanol production and ethanol yield values by $S$. cerevisiae, $P$. stipitis and Z. mobilis in SSSF using CFM pretreated by autohydrolysis of 7.71, 8.78 and $7.63 \mathrm{~g} / \mathrm{L}, 90.09 \%, 87.25 \%$ and $89.16 \%$, respectively. These results corroborate the results reported in this work for SSSF.

The ethanol production by S. cerevisiae, P. stipitis and Z. mobilis using fermentative strategies SSSF and SSF was evaluated statistically using ANOVA and $t$-test (confidence level 95\%). The ethanol production by the microorganisms using SSF showed no significant differences, when evaluated by the ANOVA. A similar result was also obtained from the microorganisms using SSSF. The comparison between the results obtained by $S$. cerevisiae using SSF and $S$. cerevisiae using SSSF showed a significant difference, when evaluated by the $t$-test. A similar result was also shown for Z. mobilis.

Results obtained for ethanol production, ethanol yield and volumetric productivity with the SSSF strategy are slightly higher compared with SSF (see Table 5). The higher fermentative efficiency for SSSF may be explained by the application of the short presaccharification period that can enhance the conversion of cellulose to glucose and, in sequence to ethanol, thus, resulting in a decrease in the enzymatic inhibition. Furthermore, the short presaccharification process increases the solubility of the substrate, leading to the improved mass transfer of nutrients to the microorganism. Another important issue related to ethanol production is the need to increase cellulosic ethanol concentration to reduce costs in the distillation process. The use of a processing step, such as suggested in SSSF, that allows for high solids loading as a result of the reduction of fermentation medium viscosity may have a positive impact on the overall process [26,39].

In this sense, fermentative strategies SHF, SSF and SSSF were evaluated by some authors. For example, Santos et al. [25] carried out fermentation with S. cerevisiae in SHF (72 h), SSF (24 h), SSSF I (16 h of presaccharification and $24 \mathrm{~h}$ of SSF) and SSSF II (16 h of presaccharification and $24 \mathrm{~h}$ of SSF) with pretreated sugarcane bagasse by steam explosion and delignified with sodium hydroxide. The best results for the volumetric productivities of ethanol were obtained in SSSF I and SSSF II, $0.29 \mathrm{~g} /(\mathrm{L} \mathrm{h})$ and $0.30 \mathrm{~g} /(\mathrm{L} \mathrm{h})$, respectively. Mesa et al. [16] reported that from 1 ton of sugarcane bagasse it is possible to obtain $192 \mathrm{~L}, 172 \mathrm{~L}$ and $198 \mathrm{~L}$ of ethanol from SHF, SSF and SSSF, respectively. They concluded that SSSF is the best process strategy based on ethanol yield and volume of produced ethanol. These results demonstrate the importance of performing the stage of presaccharification before the fermentative process and corroborate with the results obtained in this work.

\section{Conclusion}

The CFM pretreated by HPCSH showed promising results for application as substrate in the bioethanol production with high conversions of CFM into glucose during the $\mathrm{EH}$ and ethanol by the fermentative strategies of SSF and SSSF. Moreover, the liquors of CFM pretreated by HPCSH contained a high content of lignin (high quality) and phenolics that could be recovered by precipitation for further utilization according to the biorefinery concept. It is also shown that the most efficient microorganism to be used in the production of bioethanol depends on the operational strategy used.

Fig. 6. Fermentation in SSF and SSSF of CFM pretreated by HPCSH $(2.5 \%(v / v))$ sodium hydroxide at $180{ }^{\circ} \mathrm{C}$ for $30 \mathrm{~min}$ ). A) S. cerevisiae; B) P. stipitis; C) Z. mobilis. The SSF was represented by the black icon and SSSF was represented by the white icon. 
Table 5

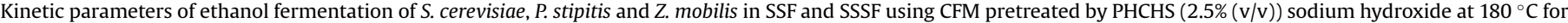
$30 \mathrm{~min})$.

\begin{tabular}{|c|c|c|c|c|}
\hline Bioprocess & Microorganism & Ethanol yield (\%) & Ethanol production $(\mathrm{g} / \mathrm{L})$ & Ethanol productivity $\mathrm{g} /(\mathrm{L} h)$ \\
\hline \multirow[t]{3}{*}{ SSF } & S. cerevisiae & $85.31 \pm 1.17$ & $10.91 \pm 0.15$ & $0.30 \pm 0.15$ \\
\hline & P. stipitis & $87.44 \pm 1.79$ & $10.96 \pm 0.22$ & $0.23 \pm 0.22$ \\
\hline & Z. mobilis & $84.56 \pm 1.65$ & $10.81 \pm 0.21$ & $0.30 \pm 0.21$ \\
\hline \multirow[t]{3}{*}{ SSSF } & S. cerevisiae & $91.17 \pm 1.46$ & $11.65 \pm 0.19$ & $0.32 \pm 0.19$ \\
\hline & P. stipitis & $90.18 \pm 1.89$ & $11.29 \pm 0.24$ & $0.24 \pm 0.24$ \\
\hline & Z. mobilis & $91.03 \pm 0.68$ & $11.64 \pm 0.09$ & $0.32 \pm 0.09$ \\
\hline
\end{tabular}

\section{Acknowledgments}

The authors gratefully acknowledge the Brazilian research funding agencies CNPq (Proc:470356/2011-1) and CAPES (Proc:BEX5951/ 11-9) for financial support.

\section{References}

[1] K. Hofsetz, M.A. Silva, Brazilian sugarcane bagasse: energy and non-energy consumption, Biomass Bioenergy 46 (2012) 564-573.

[2] FAO, World Production, Available in: www.faostat.org.br (access in: 10.01.12).

[3] IBGE. Instituto Brasileiro de Geografia e Estatística, Levantamento Sistemático da produção Agrícola: pesquisa mensal de previsão e acompanhamento das safras agrícolas no ano civil, Fundação Instituto Brasileiro de Geografia e Estatística, Rio de Janeiro, 2012.

[4] F.A. Gonçalves, E.S. dos Santos, G.R. de Macedo, Use of cultivars of low cost, agroindustrial and urban waste in the production of cellulosic ethanol in Brazil: a proposal to utilization of microdistillery, Renew. Sust. Energy Rev. 50 (2015) 1287-1303.

[5] B. Yang, C.E. Wyman, Pretreatment: the key to unlocking low cost cellulosic ethanol, Biofuels Bioprod. Biorefining 2 (2008) 26-40.

[6] M. Galbe, G. Zacchi, Pretreatment: the key to efficient utilization of lignocellulosic materials, Biomass Bioenergy 46 (2012) 70-78.

[7] J.Y. Park, M. Kang, J.S. Kim, J.P. Lee, W.I. Choi, J.S. Lee, Enhancement of enzymatic digestibility of Eucalyptus grandis pretreated by $\mathrm{NaOH}$ catalyzed steam explosion, Bioresour. Technol. 123 (2012) 707-712.

[8] G. Garrote, J.M. Cruz, A. Moure, H. Domínguez, J.C. Parajó, Antioxidant activity of byproducts from the hydrolytic processing of selected lignocellulosic materials, Trends Food Sci. Technol. 15 (2004) 191-200.

[9] R. Rawat, B.K. Kumbhar, L. Tewari, Optimization of alkali pretreatment for bioconversion of poplar (Populus deltoides) biomass into fermentable sugars using response surface methodology, Ind. Crop Prod. 44 (2013) 220-226.

[10] I. Kim, J.I. Han, Optimization of alkaline pretreatment conditions for enhancing glucose yield of rice straw by response surface methodology, Biomass Bioenergy 46 (2012) 210-217.

[11] I. Egüés, C. Sanchez, I. Mondragon, J. Labidi, Effect of alkaline and autohydrolysis processes on the purity of obtained hemicelluloses from corn stalks, Bioresour. Technol. 103 (2012) 239-248.

[12] H.R. Ghatak, Spectroscopic comparison of lignin separated by electrolysis and acid precipitation of wheat straw soda black liquor, Ind. Crop Prod. 28 (2008) 206-212.

[13] M.R. Barroso, L. Barros, M. Dueñas, A.M. Carvalho, C. Santos-Buelga, I.P. Fernandes, M.F. Barreiro, I.C.F.R. Ferreira, Exploring the antioxidant potential of Helichrysum stoechas (L.) Moench phenolic compounds for cosmetic applications: chemical characterization, microencapsulation and incorporation into a moisturizer, Ind. Crop Prod. 53 (2014) 330-336.

[14] J. Shen, F.A. Agblevor, Modeling semi-simultaneous saccharification and fermentation of ethanol production from cellulose, Biomass Bioenergy 34 (2010) 1098-1107.

[15] F.A. Gonçalves, H.A. Ruiz, C.C. Nogueira, E.S. dos Santos, J.A. Teixeira, G.R. de Macedo, Comparison of delignified coconuts waste and cactus for fuel-ethanol production by the simultaneous and semi-simultaneous saccharification and fermentation strategies, Fuel 131 (2014) 66-76.

[16] L. Mesa, E. González, I. Romero, E. Ruiz, C. Cara, E. Castro, Comparison of process configurations for ethanol production from two-step pretreated sugarcane bagasse, Chem. Eng. J. 175 (2011) 185-191.

[17] A. Sluiter, B. Hames, D. Hyman, C. Payne, R. Ruiz, C. Scarlata, J. Sluiter D. Templeton, J. Wolfe, Determination of Total Solids in Biomass and Total Dissolved Solids in Liquid Process Samples, National Renewable Energy Laboratory, Colorado: Golden, 2008.

[18] A. Sluiter, B. Hames, R. Ruiz, C. Scarlata, J. Sluiter, D. Templeton, Determination of Ash in Biomass, National Renewable Energy Laboratory, Colorado: Golden, 2005.

[19] L. Segal, J. Creely, A.J. Martin, C. Conrad, An empirical method for estimating the degree of crystallinity of native cellulose using the X-ray diffractometer, Text. Res. J. 29 (1959) 786-794.

[20] G. Garrote, H. Domínguez, J.C. Parajó, Manufacture of xylose-based fermentation media from corncobs by posthydrolysis of autohydrolysis liquors, Appl. Biochem. Biotechnol. 95 (2001) 195-207.

[21] V.L. Singleton, R. Orthofer, R.M. Lamuela-Raventos, Analysis of total phenols and other oxidation substrates and antioxidants by means of folin-ciocalteu reagent, Method Enzymol. 299 (1999) 152-178.

[22] M. Mandels, R. Andreotti, C. Roche, Measurement of saccharifying cellulase, Biotechnol. Bioeng. Symp. 6 (1976) 21-23.

[23] G.L. Miller, Use of dinitrosalicylic acid reagent for determination of reducing sugars, Anal. Chem. 31 (1959) 426-428.

[24] N. Dowe, J. Mcmillan, SSF Experimental Protocols-lignocellulosic Biomass Hydrolysis and Fermentation. NERL Analytical Procedure, National Renewable Energy Laboratory, Colorado: Golden, 2001.

[25] J.R.A. Santos, A.M. Souto-Maior, E.R. Gouveia, C. Martin, Comparação entre processos em SHF e em SSF de bagaço de cana-de-açúcar para a produção de ethanol por Saccharomyces cerevisiae, Quim. Nova 33 (2010) 904-908.

[26] C.J.A. De Souza, D.A. Costa, M.Q.R.B. Rodrigues, A.F. dos Santos, M.R. Lopes, A.B.P. Abrantes, P.S. Costa, W.B. Silveira, F.M.L. Passos, L.G. Fietto, The influence of presaccharification, fermentation temperature and yeast strain on ethanol production from sugarcane bagasse, Bioresour. Technol. 109 (2012) 63-69.

[27] I. Ballesteros, M.J. Negro, J.M. Oliva, A. Cabañas, P. Manzanares, M. Ballesteros, Ethanol production from steam-explosion pretreated wheat straw, Appl. Biochem. Biotechnol. 129/132 (2006) 496-508.

[28] Y. Pu, F. Hu, F. Huang, B.H. Davison, A.J. Ragauskas, Assessing the molecular structure basis for biomass recalcitrance during dilute acid and hydrothermal pretreatments, Biotechnol. Biofuel 6 (2013) 1-13.

[29] H. Faustino, N. Gil, C. Baptista, A.P. Duarte, Antioxidant activity of lignin phenolic compounds extracted from kraft and sulphite black liquors, Molecules 15 (2010) 9308-9322.

[30] Y.C. Sun, J.K. Xu, F. Xu, R.C. Sun, Efficient separation and physicochemical characterization of lignin from eucalyptus using ionic liquid-organic solvent and alkaline ethanol solvent, Ind. Crop Prod. 47 (2013) 277-285.

[31] R. Sun, J. Tomkinson, W. Zhu, S.Q. Wang, Delignification of maize stem by peroxymonosulfuric acid, peroxyformic acid, peracetic acid and hydrogen peroxide. 1. Physicochemical and structural characterization of the solubilized lignins, J. Agric. Food Chem. 48 (2000) 1253-1262.

[32] S.S.Y. Tan, D.R. MacFarlane, J. Upfal, L.A. Edye, W.O.S. Doherty, A.F. Patti, J.M. Pringle, J.L. Scott, Extraction of lignin from lignocellulose at atmospheric pressure using alkylbenzenesulfonate ionic liquid, Green Chem. 11 (2009) $339-345$.

[33] J. Rencoret, G. Marques, A. Gutiérrez, L. Nieto, J. Jiménez-Barbero, A.T. Martinez, J.C. del Río, Isolation and structural characterization of the milled-wood lignin from Paulownia fortunei wood, Ind. Crop. Prod. 30 (2009) $137-143$.

[34] H.P. Yang, R. Yan, H.P. Chen, D.H. Lee, C.G. Zheng, Characteristics of hemicellulose, cellulose and lignin pyrolysis, Fuel 86 (2007) 1781-1788.

[35] H.A. Ruiz, A.A. Vicente, J.A. Teixeira, Kinetic modeling of enzymatic saccharification using wheat straw pretreated under autohydrolysis and organosolv process, Ind. Crop Prod. 36 (2012) 100-107.

[36] G. Chaudhary, L.S. Singh, S. Ghosh, Alkaline pretreatment methods followed by acid hydrolysis of Saccharum spontaneum for bioethanol production, Bioresour. Technol. 124 (2012) 111-118.

[37] P. Vaithanomsat, W. Apiwatanapiwat, N. Chumchuent, W. Kongtud, S. Sundhrarajun, The potential of coconut husk utilization for bioethanol production, Kasetsart J. 45 (2011) 159-164.

[38] H. Franco, A. Ferraz, A.M.F. Milagres, W. Carvalho, J. Freer, J. Baeza, R.T. Mendonça, Alkaline sulfite/anthraquinone pretreatment followed by disk refining of Pinus radiate and Pinus caribaea wood chips for biochemical ethanol production, J. Chem. Technol. Biotechnol. 87 (2012) 651-657.

[39] K. Öhgren, J. Vehmaanperä, M. Siika-Aho, M. Galbe, L. Viikari, G. Zacchi, High temperature enzymatic prehydrolysis prior to simultaneous saccharification and fermentation of steam pretreated corn stover for ethanol production, Enzyme Microb. Technol. 40 (2007) 607-613. 